doi: 10.18575/msrs.sm.e.17.16 UDC 618.414.7-022.1:618.39 COBISS.RS-ID 6834968

\title{
Interleukin 6 in Maternal Serum as Marker of Bacterial Infection and Preterm Delivery
}

\begin{abstract}
Introduction: Preterm delivery remains a burning issue all over the world, especially in Serbia because of the rate of negative natural increase. IL-6 can stimulate the release of prostaglandins and cause premature contractions and premature labor.
\end{abstract}

Aim of the Study: The aim of this research is to examine the importance of infection in the occurrence of premature contractions and to examine whether the preterm labor is associated with increased concentrations of IL-6 in patients with intact fetal membranes.

Patients and Methods: We examined 83 pregnant women. The age range was between 15 and 43 years. The experimental group had 53 pregnant women and a control group was consisted of 30 pregnant women. All pregnant women had singleton pregnancies. The age of pregnancy in both groups was between the 21 st and 35th week of gestation. The experimental group was divided into three groups according to the localization of infection: bacterial vaginosis, an infection of the cervix and urinary tract infections. The laboratory identification of IL-6 was performed as a double sandwich ELISA method. The reagents used for the identification of IL-6 were manufactured by Beckman-Coulter and were strictly intended for the research.

Results: There were 34 pregnant women or $64 \%$ with infection of the cervix, 26 pregnant women or $49 \%$ had a positive urine culture, while bacterial vaginosis was present in 47 pregnant women or $89 \%$. A positive finding on all localization was found in 14 pregnant women or $26 \%$. In the experimental group, IL-6 was detected in 37 pregnant women or $70 \%$. The mean value of IL-6 proven in the experimental group was $20.6 \mathrm{pg} / \mathrm{ml}(\mathrm{SD}=18.2, \mathrm{n}=53)$.

Conclusion: This research demonstrated a direct link between a bacterial infection and preterm delivery. IL-6 can be used as a serological marker of bacterial infection and preterm delivery.

Key words: Interleukin-6, bacterial infections, premature birth, serologic tests
Želimir Erićc Aleksandra Patić Mirjana Bogavac ${ }^{3}$, Snežana Petrović Tepićc ${ }^{4}$

${ }^{1}$ Department of Physiology, Faculty of Medicine, University of Banjaluka, BiH

${ }^{2}$ Center for Virology, Institute of Public Health of Vojvodina, Novi Sad, Serbia

${ }^{3}$ Department of Gynecology and Obstetrics, Clinical Centre of Vojvodina, Novi Sad, Serbia ${ }_{4}$ Clinic of Pediatric Diseases, University Clinical Centre of the Republic of Srpska, Banja Luka, BiH

\section{Contact address:}

Želimir Erić

Department of Physiology

Faculty of Medicine, University of Banja Luka

Street address: Save Mrkalja 14 78 ooo Banja Luka Republic of Srpska Bosnia i Herzegovina e-mail:zelimireric@gmail.com zelimir.eric@med.unibl.org phone number: +387-51-234-151 fax: $+387-51-215-454$ 


\section{Introduction}

Preterm birth is the end of pregnancy before the $37^{\text {th }}$ week of gestation. Prematureness is an important single cause of neonatal morbidity, mortality and late consequences of survivors. ${ }^{1}$ From an etiological point of view, one third of preterm births is caused by infection and premature rupture of the fetal membranes (PROM). One third is due to maternal and fetal factors and the last third, which according to some data goes up to $50 \%$, is of unknown cause. There is evidence that an increase of IL-6 levels in amniotic fluid is associated with frequent spontaneous abortions, intrauterine fetal deaths and spontaneous premature births. ${ }^{1}$ An increase of IL-6 levels is often the result of a subclinical infection of various genital tract localities. The infection is usually present for several weeks before the possibility of the onset of premature birth or unwanted complications. ${ }^{1}$ Along with IL-6, the level of proinflammatory cytokines IL-1 and TNF- $\alpha$ in intrauterine infection and premature birth also increases in amniotic fluid., ${ }^{1,2}$ The relationship between the two subpopulations of Th1 and Th2 cells (lymphocytes) affects the secretion of cytokines and the immune status of the pregnant woman..$^{3-5}$ Cellular immunity is mostly dependent on Th1 cells, while humoral immunity predominantly depends on Th2 cells. ${ }^{6}$ At the beginning of pregnancy, the influence of Th1 cells is dominant. The balance exists in the second trimester, while the influence of Th2 cells is dominant before the end of pregnancy. ${ }^{3,7}$ Th1 cells were involved in the pathogenesis of premature labor, preeclampsia and spontaneous abortion, while Th2 cells were predominantly due to successfully delivered pregnancy. ${ }^{8-10}$ Proinflammatory cytokines were identified in amniotic fluid, maternal and fetal blood and vaginal fluid.

\section{Aim of the Study}

The aim of this study is to demonstrate the correlation between the presence of infection (bacterial infections of the cervix, bacterial vaginosis and urinary infections) and increased level of interleukin 6 in the maternal serum. The second aim is to investigate whether the level of the measured values of interleukin 6 can be used in the detection of early intrauterine infection and premature birth, in pregnant women with intact fetal membranes.

\section{Patients and Methods}

83 pregnant women participated in this research. In the experimental group, there were pregnant women $(n=53)$ hospitalized due to the symptoms of premature labor in which during the hospitalization infection was found at least in one of the examined localizations: vaginal swab, cervical swab and urine culture test. The experimental group of pregnant women was divided according to the localization of bacterial infection into three following groups:

1. Positive bacteriological findings of the cervical swab

2. Presence of bacterial vaginosis (Nugent's scoring system)

\section{Positive urine culture}

The control group consisted of healthy pregnant women $(n=30)$ who were included in the research based on the identical initial criteria as pregnant women of the experimental group. They were hospitalized due to prenatal diagnosis indicated by geneticists, due to biochemical markers or data on the birth of children with genetic malformations in previous pregnancies. It had been confirmed that the karyotypes were normal.

Clinical treatment, microbiological and immunological examination of markers were carried out in hospitalized patients with proven infection in at least one of the examined localizations, then documented contractions of the uterus (at least three in ten minutes), but with intact fetal membranes and without progressive changes of the cervix. The gynecological and ultrasound examination (SonoAce X6, "Samsung Medison") was performed by the doctors at the Department of Pathology of Pregnancy, Clinic for Gynecology and Obstetrics Clinical Centre Vojvodina. The $5 \mathrm{ml}$ of full vein blood was taken early in the morning without anticoagulants. Such blood was left to coagulate for 30 minutes, after which it centrifuged at $3000 \mathrm{rpm}$ for ten minutes. The separated serum was frozen at $-70^{\circ}$. It was kept up to the moment of the definitive laboratory processing of the examined series. The identification of interleukin 6 from the patient's serum was done by a double sandwich ELISA method, an open system apparatus. Reagents used to identify interleukin 6 were manufactured by Beckman \& Coulter and were designed strictly for research. The values obtained for these parameters were determined according to the tables and values given by the producer. In the second phase of the study, obtained vaginal, cervical swabs and urine were processed to identify the present bacterial flora. The bacterial diagnosis was based on the microscopy and cultivation of the taken material by examining: Gram-positive, Gram-negative bacteria and fungi. Before sowing, a direct preparation was made and painted according to Gram stain procedure.

\section{Results}

83 pregnant women were analyzed. There were 53 pregnant women in the experimental group who had an infection of at least one examined localization. Of these 53 
patients, 34 or $64 \%$ were with cervical infection. Positive urine culture had 26 pregnant women or $49 \%$, while 47 pregnant women or $89 \%$ had bacterial vaginosis. Two patients only had cervical infection, one patient had only positive urine culture, while 10 pregnant women only had bacterial vaginosis. However the most pregnant women had joint infections and infections present in more than one investigated localization. Three pregnant women had positive urine culture and a positive cervical swab. Eight patients had a positive urine culture and bacterial vaginosis. 15 pregnant women had bacterial vaginosis and positive bacteriological finding on the cervix. A total of 26 pregnant women had two positive findings of possible three different localities. 14 pregnant women or $26 \%$ had a positive finding in all localities.

The average age of all pregnant women was 28 years
$(\mathrm{SD}=6.2, \mathrm{n}=83)$. For the experimental group, the average was 27 years $(\mathrm{SD}=6.1, \mathrm{n}=53)$ while the control group was 29 years old $(\mathrm{SD}=6.2, \mathrm{n}=30)$. The youngest pregnant woman in the experimental group was 15 , while in the control group the youngest pregnant woman was 18 years old. The oldest pregnant woman in the experimental group was 43 years old, while the oldest pregnant woman in the control group was 40 years old. Between the groups, there was no statistically significant difference $(\mathrm{p}=0.247)$ in the age. (Table 1.$)$

The gestational age in both groups was between the 21 and 35 week.

The mean gestational age in the experimental group was 25 weeks $(\mathrm{SD}=3.9, \mathrm{n}=53)$, while the mean age in the control group was 26 weeks of gestation $(\mathrm{SD}=5 \cdot 1, \mathrm{n}=30)$.

Table 1. The average of the age of pregnant women and gestational age

\begin{tabular}{|c|c|c|c|c|c|c|c|c|c|c|c|c|}
\hline \multirow[b]{2}{*}{ Groups } & \multicolumn{8}{|c|}{ The average of the age of pregnant women } & \multicolumn{4}{|c|}{ Gestational age } \\
\hline & $\mathrm{N}$ & Average & SD & Min & Max & $\begin{array}{c}P \\
\text { t-test }\end{array}$ & $\mathrm{N}$ & Average & SD & Min & Max & $P$ t-test \\
\hline Experimental & 53 & 27.4 & 6.1 & 15 & 43 & \multirow[t]{3}{*}{0.247} & 53 & 25.2 & 3.9 & 21 & 35 & \multirow[t]{3}{*}{0.270} \\
\hline Control & 30 & 29.0 & 6.2 & 18 & 40 & & 30 & 26.3 & 5.1 & 21 & 35 & \\
\hline Total & 83 & 28.0 & 6.2 & 15 & 43 & & 83 & 25.6 & 4.4 & 21 & 35 & \\
\hline
\end{tabular}

The average gestational age for all pregnant women was 26 weeks $(\mathrm{SD}=4.4, \mathrm{n}=83)$. (Table 1 .)

The following bacteria of the cervical swab were identified as Streptococcus agalactiae, Enterococcus, Staphylococcus aureus, Staphylococcus species, Citrobacter, Escherichia coli, Klebsiella pneumoniae and Proteus mirabilis. Positive bacteriological findings of the cervix were present in 28 pregnant women. Six pregnant women had Candida albicans. 34 pregnant women of the experimental group had a positive finding of the cervix. Streptococcus agalactiae and Enterococcus were present in eight pregnant women, Staphylococcus aureus in two, Staphylococcus species in three, Citrobacter in one, Escherichia coli in four, Klebsiella pneumoniae in, Proteus mirabilis in one, while Candida albicans was found in six pregnant women.

27 patients of this group did not have positive urine culture. According to the positive findings of urine culture, the following bacteria were identified: Streptococcus agalactiae, Enterococcus, Staphylococcus species, Escherichia coli and Klebsiella pneumoniae. A positive finding of urine culture was present in 26 pregnant women, Streptococcus agalactiae in six, Enterococcus in four, Staphylococcus species in two, while Escherichia coli was present in 13 pregnant women. Klebsiella pneumoniae was found in one pregnant woman.

The average value for IL-6 in both groups was $16.7 \mathrm{pg} /$ $\mathrm{ml}(\mathrm{SD}=16.5, \mathrm{n}=83)$. The lowest measured value was 3.61 $\mathrm{pg} / \mathrm{ml}$ in both groups. The highest measured value for IL-6 of the experimental group was $84.6 \mathrm{pg} / \mathrm{ml}$, while the maximum value for IL-6 of the control group was 15.0 $\mathrm{pg} / \mathrm{ml}$ (Table 2.). Determination of $3 \mathrm{pg} / \mathrm{ml}$ means that the measurement method used was able to measure only the values of IL- 6 which were greater than the detection threshold of $3 \mathrm{pg} / \mathrm{ml}$.

Parameters which were measured had a large range of values and the distribution of the measured values did not have a bell curve arrangement. The standard deviation (SD) values in this study were extremely high. This can be explained by a small sample within the available resources for this research. According to the distribution shown in the analysis, the Mann-Whitney test method was used. Statistical analysis found that IL-6 values in the experimental group were significantly higher than 
values in the control group $(\mathrm{p}=0.001)$.

Table 2. The average values of IL-6

\begin{tabular}{|c|c|c|c|c|c|c|}
\hline \multicolumn{7}{|c|}{ The value of IL-6 } \\
\hline Groups & $\mathrm{N}$ & Average & SD & Min & Max & $\begin{array}{c}\mathrm{P} \\
\text { Mann } \\
\text { Whitney }\end{array}$ \\
\hline $\begin{array}{l}\text { Experi- } \\
\text { mental }\end{array}$ & 53 & 20.6 & 18.2 & 3.61 & 84.6 & 0.001 \\
\hline Control & 30 & 7.33 & 3.72 & 3.61 & 15.0 & \\
\hline Total & 83 & 16.7 & 16.5 & 3.61 & 84.6 & \\
\hline
\end{tabular}

\section{Discussion}

The most important risk factors for a preterm delivery are multiple pregnancies, previous premature births, bleeding after the first trimester of pregnancy and low Body Mass Index (BMI). ${ }^{10}$ Results of Mijovic et al. showed that bacterial vaginal infection was statistically more commonly diagnosed in third trimester in women who gave birth in a preterm (66.7\%), compared to women who gave birth in a term (29.9\%). ${ }^{11}$ Some studies indicate an increased risk of spontaneous preterm labor before the 34th week of gestation in pregnant women in which serum reduced values of IL-18 and elevated levels of IL12 are found. ${ }^{12-14}$

Increased level of IL-6 in serum is associated with preterm delivery in Caucasians but not in the black population. ${ }^{15}$ Large studies which have examined the vaginal flora indicate that bacterial vaginosis is more present in black pregnant women, even in the same degree of health care. ${ }^{16,17}$

Pregnant women over 35 years of age in the first trimester of pregnancy have an increased levels of IL- 6 and TNF- $\alpha$ in serum, compared to women under 35 years of age. ${ }^{17,18}$ IL- 6 and IFN- $\gamma$ have not been associated with all preterm deliveries before 37th weeks of gestation but are associated with premature birth and pregnant women under the $35^{\text {th }}$ week of gestation who have proven horioamnionitis. ${ }^{8}$ It has been shown there are no significant differences of serum levels of interleukins in pregnant women who have repeated premature births. ${ }^{19}$

The data of several comparative studies of the level of circulating cytokines in the first and second trimester of pregnancy show contradictory results. Some studies have shown and demonstrated the increased levels of
IL-6 during pregnancy while others find no significantly increased level of IL-6 until the onset of delivery. ${ }^{16,20}$ Many studies have attempted to identify a biomarker, a combination of multiple or clinical symptoms in order to facilitate the detection of pregnant women with an accompanying preterm delivery. If we want to overcome the above mentioned health problem successfully, it is necessary to analyze the existing approaches and methods in this field and to develop a wider multidisciplinary approach of research. ${ }^{21}$

Although studies show elevated values of different cytokines, the analysis of these results, which shows that the immune response in pregnancy is extremely complex, implies the interconnection of several different factors, which requires caution..$^{22,23}$ The premature opening of cervix without infection is basically a type of inflammatory reaction as well as cervical enlargement at the time of term delivery. ${ }^{24,25}$ The differences that exist in different studies may be due to differences in a sample size. Comparison of different studies or level of cytokines may be limited by using different immunoassays, different population structure, laboratory methods and plasma or serum use. ${ }^{23}$ Recent studies have similar results as the conducted research. Marconi et al. conducted a study in which they also demonstrated the correlation of preterm delivery with elevated values of IL-6. ${ }^{26}$

The influence of infection or other immune stimulants for cytokine levels is documented. There are still many unknown facts about how cytokine levels vary in pregnancy and depend on other maternal and fetal factors.

\section{Conclusion}

This research demonstrated a direct link between bacterial infection and preterm delivery. IL-6 can be used as a serological marker of bacterial infection and preterm delivery.

\section{References}

1. Goldenberg L, Hauth C, Andrews W. Intrauterine infection and preterm delivery. N Eng J Med 2000;342:1500-7. https://doi.org/10.1056/NEJM200005183422007 PMid:10816189

2. Satoshi Y, Masatoshi S, Yasushi S, Arihiro S, Takao H, Shigeru S. Interleukin-8 and glucose in amniotic fluid, fetal fibronectin in vaginal secretions and preterm labor index based on clinical variables are optimal predictive markers for preterm delivery in patients with intact membranes. J Obstet Gynaecol Res 2007;33:38-44. https://doi.org/10.1111/j.1447-0756.2007.00474.x PMid:17212664

3. Aris A, Lambert F, Bessette P, Moutquin JM. Maternal 
circulating interferon- $\gamma$ and interleukin- 6 as biomarkers of Th1/Th2 immune status throughout pregnancy. J Obstet Gynaecol Res 2008; 34:7-11.

PMid:18226122

4. Belardelli F. Role of interferons and other cytokines in the regulation of the immune response. Apmis 1995;103:16179 .

https://doi.org/10.1111/j.1699-0463.1995.tbo1092.x PMid:7538771

5. Raghupathy R. Th1-type immunity is incompatible with successful pregnancy. Immunol Today 1997;18:478-82. https://doi.org/10.1016/So167-5699(97)01127-4

6. Wilczynski JR. Th1/Th2 cytokines balance-yin and yang of reproductive immunology. Eur $\mathrm{J}$ Obstet Gynecol Reprod Biol 2005;122:136-43.

https://doi.org/10.1016/j.ejogrb.2005.03.008 PMid:15893871

7. Darmochwal-Kolarz D, Leszczynska-Gorzelak B, Rolinski J, Oleszczuk J. T helper 1 and T helper 2-type cytokine imbalance in pregnant women with preeclampsia. Eur $\mathrm{J}$ Obstet Gynecol Reprod Biol 1999;86:165-70. https://doi.org/10.1016/So301-2115(99)00065-2

8. Warner Gargano J, Holzmana C, Senagore P, Thorsen P, Skogstrand K, Hougaard DM et al. Mid-pregnancy circulating cytokine levels, histologic chorioamnionitis and spontaneous preterm birth. $\mathrm{J}$ Reprod Immunol 2008;79:100-10.

https://doi.org/10.1016/j.jri.2008.o8.oo6PMid:18814919 PMCid:PMC2683663

9. Daher S, Arruda Geraldes Denardi K, Blotta MH, Mamoni RL, Reck AP, Camano L et al. Cytokines in recurrent pregnancy loss. J Reprod Immunol 2004;62:15157. https://doi.org/10.1016/j.jri.2003.10.004 PMid:15288190

10. McManemy J, Cooke E, Amon E, Leet T. Recurrence risk for preterm delivery. Am J Obstet Gynecol 2007;196:576. e1-576.e7.

https://doi.org/10.1016/j.ajog.2007.01.039

PMid:17547902

11. Mijović G, Lukić G, Jokmanović N, et al. Uticaj bakterijske vaginalne cervikalne kolonizacije/infekcije na nastanak prevremenog porođaja. Vojnosanit Pregl 2008;65:273-80. PMid:18499947

12. Hack M, Fanaroff A. Outcomes of extremely immature children-a perinatal dilemma. $\mathrm{N}$ Engl J Med 1993;329:1649-50.

https://doi.org/10.1056/NEJM199311253292210 PMid:8232435

13. Ekulend CK, Vogel I, Skogstrand K, Thorsen P, Hougaard DM, Langhoff-Roos $\mathrm{J}$ et al. Interleukin-18 and interleukin-12 in maternal serum and spontaneous preterm delivery. J Reprod Immunol 2008;77:179-85. https://doi.org/10.1016/j.jri.2007.07.002 PMid:17850880

14. Pararas M, Skevaki C, Kafetzis D. Preterm birth due to maternal infection: causative pathogens and modes of prevention. Eur J Clin Microbiol Infect Dis 2006;25:56269.

https://doi.org/10.1007/s10096-006-0190-3 PMid:16953371

15. Menon R, Camargo M, Thorsen P, Lombardi SJ, Fortunato SJ. Amniotic fluid interleukin-6 increase is an indicator of spontaneous preterm birth in white but not black Americans. Am J Obstet Gynecol 2008;198:77.e1-7. https://doi.org/10.1016/j.ajog.2007.06.071 PMid:18166313

16. Curry AE, Vogel I, Drews C, Schendel D, Skogstrand K, Flanders WD et al. Maternal plasma cytokines in early and mid-gestation of normal human pregnancy and their association with maternal factors. $J$ Reprod Immunol 2008;77:152-60.

https://doi.org/10.1016/j.jri.2007.06.051

PMid:17692390

17. Christiaens I, Zaragoza D, Guilbert L, Robertson S, Mitchell B, Olson D. Inflammatory processes in preterm and term parturition. J Reprod Immunol 2008;79:50-57.

https://doi.org/10.1016/j.jri.2008.04.002

PMid: 18550178

18. Chow SS, Craig ME, Jones CA, Hall B, Catteau J, Lloyd AR et al. Differences in amniotic fluid and maternal serum cytokine levels in early midtrimester women without evidence of infection. Cytokine 2008;44:78-84

https://doi.org/10.1016/j.cyto.2008.06.009 PMid:18703348

19. Mercer B, Macpherson C, Goldenberg RL, Goepfert AR, Haugel-De S, Varner $\mathrm{M}$ et al. Are women with recurrent spontaneous preterm births different from those without such history? Am J Obstet Gynecol 2006;194:1176-85. https://doi.org/10.1016/j.ajog.2006.01.069 PMid:16580328

20. Bombell S, Mcguire W. Cytokine polymorphisms in women with recurrent pregnancy loss: Meta-analysis. Aust N Z J Obstet Gynaecol 2008;48:147-54. https://doi.org/10.1111/j.1479-828X.2008.00843.x PMid:18366487

21. Tribe R. A translational approach to studying preterm labour. BMC Pregn Childb 2007;7:S1-8. Available at: http://www.biomedcentral.com/1471-2393/7/S1/S8. DOI: $10.1186 / 1471-2393-7-S 1-S 8$

22. Laudanski T, Pierzynski P, Laudanski P. Reductionist and system approaches to study the role of infection in preterm labor and delivery. BMC Pregn Childb 2007;7:S9. Available at: http://www.biomedcentral.com/1471-2393/7/S1/ S9. DOI: 10.1186/1471-2393-7-S1-S9 https://doi.org/10.1186/1471-2393-7-S1-S9

23. Ancel PY, Lelong N, Papiernik E, Saurel-Cubizolles MJ, Kaminski M. History of induced abortion as a risk factor for preterm birth in European countries: results of the EUROPOP survey. Hum Reprod 2004;19:734-40. https://doi.org/10.1093/humrep/deh107 
PMid:14998979

24. Törnblom SA, Klimaviciute A, Byström B, Chromek M, Brauner A, Ekman-Ordeberg G. Non-infected preterm parturition is related to increased concentrations of IL-6, IL-8 and MCP-1 in human cervix. Reprod Biol Endocrin 2005;3:39. DOI: 10.1186/1477-7827-3-39 https://doi.org/10.1186/1477-7827-3-39

25. Gustafsson C, Hummerdal P, Matthiesen L, Berg G, Ekerfelt C, Ernerudh J. Cytokine secretion in decidual mononuclear cells from term human pregnancy with or without labour. ELISPOT detection of IFN-gamma, IL-4, IL-10, TGF-Beta and TNF-alpha. J Reprod Immunol 2006;71:41-56.

https://doi.org/10.1016/j.jri.2005.12.009 PMid:16730071

26. Marconi C, Ribeiro de Andrade Ramos B, Peraçoli JC, Donders GG, Guimarães da Silva M. Amniotic fluid interleukin-1 beta and interleukin-6, but not interleukin- 8 correlate with microbial invasion of the amniotic cavity in preterm labor. Am J Reprod Immunol 2011;65:549-56. https://doi.org/10.1111/j.1600-0897.2010.00940.x PMid:21214658

\section{Interleukin 6 u maternalnom serumu kao marker bakterijske infekcije i prijevremenog porođaja}

\section{SAŽETAK}

Uvod: Prijevremeni porođaj je aktuelni problem u cijelom svijetu, posebno u R. Srbiji zbog negativnog prirodnog priraštaja. IL-6 može stimulisati oslobađanje prostaglandina, te samim tim uzrokovati prijevremene kontrakcije i prijevremeni porođaj.

Cilj rada: Vidjeti značaj infekcije u nastanku prijevremenih kontrakcija, te ispitati da li je prijevremeni porođaj udružen sa povećanom koncentracijom IL-6 kod trudnica sa intaktnim plodovim ovojcima.

Ispitanici i metode: Istraživanje je izvedeno na 83 trudnice starosti između 15 i 43 godine, gde je 53 trudnice činilo eksperimentalnu grupu, a 30 zdravih trudnica, kontrolnu grupu. Sve trudnice su nosile jednoplodnu trudnoću, starosti između 21. i 35. nedelje gestacije. Eksperimentalna grupa je podijeljena u tri grupe prema lokalizaciji infekcije: bakterijska vaginoza, infekcija grlića materice i urinarna infekcija. Laboratorijska identifikacija IL-6 rađena je dvostrukom sendvič ELISA metodom, aparatom otvorenog sistema. Reagensi korišteni za identifikaciju IL-6, proizvedeni su od strane Beckman-Coulter, namijenjeni striktno za istraživanje.

Rezultati: Od 53 trudnice u eksperimentalnoj grupi bilo je 34 trudnice, odnosno 64\%, sa infekcijom grlića materice, pozitivnu urino-kulturu imalo je 26 trudnica, odnosno 49\%, dok je bakterijsku vaginozu imalo 47 trudnica, odnosno 89\%. Pozitivan nalaz infekcije, na svim lokalizacijama, nađen je kod 14 trudnica, odnosno 26\%. U eksperimentalnoj grupi IL-6 je dokazan kod 37 trudnica, odnosno 70\%. Srednja vrijednost dokazanog IL-6 u eksperimentalnoj grupi iznosila je 20,6 pg/ml (SD=18.2, n=53).

Zaključak: Ovim istraživanjem dokazana je direktna povezanost bakterijske infekcije i prijevremenog porođaja. IL-6 se može koristiti kao serološki marker bakterijske infekcije i prijevremenog porođaja.

Ključne riječi: Interleukin-6, bakterijske infekcije, prijevremeni porođaj, serološki testovi 